REVISTA DE DERECHO UNED, NÚM. 14, 2014

\title{
LA REFORMA DE LOS DELITOS CONTRA LA HACIENDA PÚBLICA Y CONTRA LA SEGURIDAD SOCIAL
}

\section{(THE REFORM OF TAX FRAUD AND CRIMES AGAINST SOCIAL SECURITY)}

Alfonso Serrano Gómez y Alfonso Serrano Maíllo

UNED

Resumen: Los delitos aquí estudiados han sido objeto de diversas reformas. La última es muy extensa. El contenido de los artículos es complejo, a veces reiterativo, y como ley en blanco necesitan de un extenso apoyo de la legislación tributaria. Se destaca una finalidad recaudatoria en la reforma. Aunque en alguna ocasión se agravan las penas, los supuestos de exención de responsabilidad criminal se amplían, creando también otros atenuados que permiten rebajar la pena en uno o dos grados.

Palabras clave: Fraude tributario, regularización del fraude, atenuación de la pena.

Abstract: Tax fraud and other crimes have been subjected to a number of reforms in the last years. The last reform has been quite ample. The content of the Law is complex, sometimes reiterative. As ley en blanco it demands an extensive use of the taxing Laws for interpretation purposes. The reform obeys in part to the aim of fund raising. Though some of the penalties have been raised, the cases of penalty exemption are now extended, as well as attenuated types that allow a reduction of the penalty in one or two grades.

Key words: Tax fraud, regularization of fraud, penalty extenuation.

Recepción original: 28/04/2014

Aceptación original: 27/05/2014

(C) UNED. Revista de Derecho UNED, núm. 14, 2014 
Sumario: I. Cuestión previa. II. Fraude tributario. III. Delitos contra la seguridad social. IV. Fraude y malversación de subvenciones. V. Defraudación contable. VI. Responsabilidad de las personas jurídicas. VII. Procedimiento. VIII. Proyecto de Ley de reforma del Código penal.

\section{CUESTIÓN PREVIA}

El Título XIV del Libro II del Código penal figura bajo la rúbrica «Delitos contra la Hacienda pública y la Seguridad Social». Fue modificado en diciembre de 2012. Se incorporan tres nuevos artículos, 305 bis, 307 bis y 307 ter; se derogan el 309, 627 y 628 del Código penal; con una excepción, se modifica el resto de los artículos ${ }^{1}$. Se prevén nuevos cambios en el Proyecto de reforma del Código penal de 2013 que se está tramitando en la actualidad en el Congreso ${ }^{2}$.

El tipo básico recogido en el artículo 305.1 no varía su contenido después de la reforma. Se mantiene prácticamente igual en su párrafo primero. No obstante, a este párrafo se le añade un inciso final con el siguiente contenido: «salvo que hubiere regularizado su situación tributaria en los términos del apartado 4 del presente artículo». Este apartado se refiere a la regularización tributaria.

Este inciso final crea serios problemas en su interpretación. El legislador, como recoge en el preámbulo de la Ley, parece que pretende que la regularización es un elemento del tipo, que lleva consigo tanto

${ }^{1}$ LO 7/2012, de 27 de diciembre (BOE núm. 312, del 28), por la que se modifica la LO 10/1995, de 23 de noviembre, del Código Penal en materia de transparencia y lucha contra el fraude fiscal y en la Seguridad Social.

Se prevé rebajar la pena en uno o dos grados en el fraude tributario (artículo 305.6), delitos contra la Seguridad Social (artículo 307.5), y en el fraude y malversación de subvenciones (artículo 308.7). Estos supuestos se contemplan para quienes antes de que transcurran dos meses desde la citación judicial como imputado, reintegren el importe de la defraudación y reconozcan judicialmente los hechos. También se extiende a otros participes en el delito que colaboren con la justicia.

${ }^{2}$ El Proyecto fue aprobado en el Consejo de Ministros de 20 de septiembre de 2013 y se publica en el Boletín Oficial de las Cortes, Congreso de los Diputados, Serie A, núm. 66/1, de 4 de octubre de 2013 (Proyecto de Ley Orgánica por el que se modifica la LO 10/1995, de 23 de noviembre, del Código Penal). 
el desvalor de la acción como del resultado ${ }^{3}$, La regularización hace desaparecer el injusto, retornándose a la legalidad ${ }^{4}$.

Si no hay delito fiscal como consecuencia de la regularización, se plantearían dificultades a lo hora de determinar tanto la consumación del delito como su prescripción. La doctrina es crítica con la nueva regulación. Parece que según pretende el legislador la consumación no tendría lugar hasta que no transcurriera el plazo para la posible regularización, que serían cuatro años a partir del momento del fraude. Ello como consecuencia de que las defraudaciones a la Hacienda Pública prescriben a los cuatro años ${ }^{5}$. A partir de ese momento, sin haber regularizado, quedaría el delito consumado y comenzaría a contar la prescripción.

La regularización como excusa absolutoria. Antes de la reforma la regulación absolutoria jugaba como excusa absolutoria ${ }^{6}$. Creemos que la situación no ha variado, pues existe la comisión de un delito y autor del mismo, que como consecuencia de la regularización el legislador le exime de la pena, por cuestiones de política recaudatoria, pero no puede llevar a eliminar la tipicidad. Sería una atipicidad sobrevenida a la ejecución de los hechos.

${ }^{3}$ En el párrafo segundo del apartado III del preámbulo de la Ley se recoge: «Una primera modificación ha consistido en configurar la regularización de la situación tributaria como el verdadero reverso del delito de manera que, con la regularización, resulte neutralizado no sólo el desvalor de la acción con una declaración completa y veraz, sino también el desvalor del resultado mediante el pago completo de la deuda tributaria y no solamente de la cuota tributaria como ocurre actualmente».

${ }^{4}$ En el párrafo cuarto del apartado III del preámbulo se recoge: «En coherencia con esta nueva configuración legal de la regularización tributaria como el reverso del delito que neutraliza completamente el desvalor de la conducta y el desvalor del resultado, se considera que la regularización de la situación tributaria hace desaparecer el injusto derivado del inicial incumplimiento de la obligación tributaria y así se refleja en la nueva redacción del tipo delictivo que anuda a ese retorno a la legalidad la desaparición del reproche penal. Esta modificación se complementa con la del apartado 4 relativa a la regularización suprimiendo las menciones que la conceptuaban como una excusa absolutoria».

${ }^{5}$ Vid. artículo 66 de la Ley General Tributaria, así como apartado VII de este trabajo.

${ }^{6}$ Entre los penalistas era la postura dominante. Vid. IgLEsias Río, M. A., La regulación fiscal en el delito de defraudación tributaria: un análisis de la autodenuncia. Art. 305.4 del C. P., Valencia, 2003, págs. 211 y ss. 
Sobre esta cuestión la doctrina es crítica ${ }^{7}$, algún autor dice que se mantiene la excusa absolutoria ${ }^{8}$ y otros que cabe concebirla como tal $^{9}$. El Consejo Fiscal se pronuncia en contra ${ }^{10}$, lo mismo que el legislador, que en el preámbulo de la ley de reforma de 2012 recoge: «Esta modificación se complementa con la del apartado 4 relativa a la regularización suprimiendo las menciones que la conceptuaban como una excusa absolutoria» ${ }^{11}$.

Entendemos que la regularización sigue siendo excusa absolutoria. Lo que elimina es la punibilidad. Manteniendo esta postura la consumación del fraude tributario tendría lugar cuando la defraudación superara los ciento veinte mil euros y hubiera transcurrido el plazo legalmente establecido para efectuar la declaración voluntaria por el sujeto obligado a ello y no lo hizo. No es posible el desistimiento en la tentativa, pues se han agotado los plazos con las prórrogas concedidas por la Administración para efectuar el pago, que finaliza el último día hábil para hacer el ingreso. A partir de este momento comenzará a contar el plazo de la prescripción. No obstante habrá que esperar a ver en qué sentido se pronuncian los tribunales. Sin embargo, tal vez los estudios de dogmática consigan que los jueces acepten la situación anterior a la reforma en favor de la excusa absolutoria, aunque no es fácil ya que, como hemos visto, el legislador la excluye como tal ${ }^{12}$.

Las dificultades que presenta el nuevo texto legal pueden afectar tanto a la certeza del derecho como a la seguridad jurídica que se

${ }^{7}$ Bacigalupo, E., «La reforma del delito fiscal por la LO 7/2012», en La Ley, núm. 8076/2013. Rosal Blasco, B., «Delito fiscal y blanqueo de capitales: perspectivas ante la nueva reforma del tipo básico del delito fiscal», en idem, núm. 817/2013. SERRANo GonZÁlez de Murillo, J. L. y Merino Jara, I., «Pasado, presente y futuro de las regularizaciones tributarias en Derecho penal», en ídem, núm. 8036/2013. También DopIco Gómez-Aller, J., «La reforma del Derecho Penal Tributario: nuevas oportunidades para el fraude fiscal», en Juris, núm. 181/182, 2012, págs. 12 y ss.

${ }^{8}$ BACigalupo, en ob. cit, pág. 7, dice: «Desde mi punto de vista la regularización continuará siendo una excusa absolutoria, cuya ausencia constituye, a la vez, un presupuesto procesal de la persecución. En consecuencia la regularización no tendrá efectos sobre la prescripción del delito, pues éste se consuma con la realización de los elementos del tipo del art. 305.1 CP».

${ }^{9}$ Serrano González de Murillo y Merino Jara, en op. cit., pág. 7 escriben que sigue siendo posible concebir la regularización como excusa absolutoria.

${ }^{10} \mathrm{El}$ Consejo Fiscal, en el informe al Anteproyecto de Ley Orgánica por la que se modifica la Ley Orgánica, 10/1995, de 23 de noviembre, del Código penal, recoge en su página 11: "La modificación de este apartado se corresponde con la nueva configuración del tipo básico, en el que la regularización de la situación tributaria constituye un elemento del mismo y no, como hasta ahora, una excusa absolutoria».

${ }^{11}$ Párrafo tercero del apartado III de la LO 7/2012.

12 Vid. supra nota 4. 
contempla en el artículo 9.3 de la Constitución, tal vez nos encontremos ante un supuesto de inconstitucionalidad. La pretensión del legislador se habría prestado a menos dudas si el polémico inciso final se hubiera colocado al principio del párrafo primero del artículo 305, figurando como sigue: «El que por acción u omisión, y sin que hubiere regulado su situación tributaria en los términos del apartado 4 del presente artículo, hubiera defraudado...».

La nueva regulación de estos delitos resulta arbitraria frente a otros, como puede ser la estafa. Permite rebajar las penas en uno o dos grados siempre que el obligado tributario o el autor del delito «antes de que transcurran dos meses desde la citación judicial como imputado satisfaga la deuda tributaria y reconozca judicialmente los hechos» (artículo 305.6). Sucede lo mismo en los delitos contra la Seguridad Social (artículo 307.5) y en el reintegro de subvenciones (artículo 307). En un delito de estafa, y otros, esta rebaja de la pena no es posible, el autor podría acogerse a la atenuante $5 .^{a}$ del artículo 21 (reparación del daño), que de no estimarse como muy cualificada lleva a imponer la pena en su mitad inferior. De otra parte, en los delitos contra la Hacienda Pública y la Seguridad Social, rebajar la pena en uno o dos grados puede tener efectos criminógenos, ya que habrá a quien le compense correr el riego, pues sabe que aunque al final se le descubra y paga no irá a prisión, salvo que tuviera condenas anteriores. Tanto para los supuestos de pena de prisión de uno a cinco años, que son la mayoría, como para los agravados-pena de dos a seis años- la rebaja de la misma en uno o dos grados permite la suspensión de su ejecución, por aplicación de lo dispuesto en los artículos 80 y 81 del Código penal.

\section{FRAUDE TRIBUTARIO}

\section{Tipo básico}

Se recoge en el artículo 305.1, que dispone: «El que, por acción u omisión, defraude a la Hacienda Pública estatal, autonómica, foral o local, eludiendo el pago de tributos, cantidades retenidas o que se hubieran debido retener o ingresos a cuenta obteniendo indebidamente devoluciones o disfrutando beneficios fiscales de la misma forma, siempre que la cuantía de la cuota defraudada, el importe no ingresado de las retenciones o ingresos a cuenta o de las devoluciones o beneficios fiscales indebidamente obtenidos o disfrutados exceda de ciento veinte mil euros... salvo que hubiere regularizado su situación 
tributaria en los términos del apartado 4 del presente artículo».Pena: Prisión de uno a cinco años y multa del tanto al séxtuplo de la citada cuantía. Además, se impondrá al responsable la pérdida de la posibilidad de obtener subvenciones o ayudas públicas y del derecho a gozar de los beneficios o incentivos fiscales o de la Seguridad Social durante el período de tres a seis años.

Estamos ante un tipo penal en blanco, pues para completarlo hay que recurrir a la legislación fiscal.

El bien jurídico protegido son los intereses económicos del Estado, las Comunidades Autónomas, forales y las Entidades locales ${ }^{13}$. La doctrina no es pacífica en este punto ${ }^{14}$.

Sujeto activo del delito es el obligado al pago que realiza la conducta típica de defraudación ${ }^{15}$. Sujeto pasivo es la hacienda estatal, autonómica, foral o local.

En cuanto a la defraudación hay que entender que equivale a engaño, lo que excluye ya la comisión del delito por imprudencia.

Las conductas que se contemplan en el artículo 305.1, son:

a) Elusión del pago de tributos. No hay un concepto uniforme en la doctrina sobre este tipo de impago. Por elusión del pago de tributos hay que entender la omisión del deber que el contribuyente tiene de hacer efectiva su deuda tributaria.

De acuerdo con el artículo 305. 1 se incluye en el tipo descrito en su párrafo primero la elusión del pago de tributos a la Hacienda estatal, autonómica, foral o local.

El concepto de tributo es básico para reconocer el fraude fiscal. Estos se clasifican en tasas, contribuciones especiales e impuestos.

Según el artículo 2.2 de la Ley General Tributaria (LGT 2003): «Los tributos, cualquiera que sea su denominación, se clasifican en tasas, contribuciones especiales e impuestos: a) Tasas son los tributos cuyo hecho imponible consiste en la utilización privativa o el aprove-

${ }^{13}$ Vid. Martínez-Buján Pérez, C., Derecho penal económico y de la empresa. Parte especial, Valencia, 2005, págs. 545 y ss.

${ }^{14}$ Vid. BAL FrancÉs, E., «El bien jurídico protegido en el delito contra la Hacienda Pública» dice que el bien es «la protección del sistema fiscal como sistema equitativo de la cooperación social» en FuEnTES BARDAJí (Codirector), Manual de Delitos contra la Hacienda Pública, Pamplona, 2008, pág. 73.

${ }^{15}$ Sobre la participación de «extraneus» en el delito de defraudación tributaria vid. Silva Sánchez, J. M., El nuevo escenario del delito fiscal en España, Barcelona, 2005, págs. 53 y ss. 
chamiento especial del dominio público, la prestación de servicios o la realización de actividades en régimen de derecho público que se refieran, afecten o beneficien de modo particular al obligado tributario, cuando los servicios o actividades no sean de solicitud o recepción voluntaria para los obligados tributarios o no se presten o realicen por el sector privado. b) Contribuciones especiales son los tributos cuyo hecho imponible consiste en la obtención por el obligado tributario de un beneficio o de un aumento de valor de sus bienes como consecuencia de la realización de obras públicas o del establecimiento o ampliación de servicios públicos. c) Impuestos son los tributos exigidos sin contraprestación cuyo hecho imponible está constituido por negocios, actos o hechos que ponen de manifiesto la capacidad económica del contribuyente».

b) No ingresar cantidades retenidas o no retener las que haya obligación de hacerlo. Afecta al Impuesto sobre la Renta de las Personas Físicas. La Ley $35 / 2006^{16}$, en su artículo 99 se ocupa de la «obligación de practicar pagos a cuenta», que en todo caso tendrán la consideración de deuda tributaria. Podrán consistir en retenciones, ingresos a cuenta y pagos fraccionados ${ }^{17}$.

c) Obtención indebida de devoluciones. El autor de la defraudación consigue se le reintegre por parte de las Administraciones Publicas de una cantidad de dinero superior a ciento veinte mil euros, simulando situaciones irreales de deducciones previas no existentes.

d) Disfrute indebido de beneficios fiscales. Se sigue sin resolver lo que ha de entenderse por beneficios fiscales, que en términos generales abarcará todo tipo de bonificaciones, deducciones, desgravaciones y exenciones tributarias.

De lo anterior se desprenden las dificultades que surgen en cuanto a la interpretación de conceptos para determinar las tipologías, y aunque no estamos ante una genuina norma penal en blanco, sin embargo, con demasiada frecuencia en éste y en otros de los tipos, hay que recurrir a normas de derecho financiero o tributario ajenas al C.p. Esta es una de las razones por las que se considera que estos delitos deben tipificarse en una ley especial, como sucede con la Ley de con-

${ }^{16}$ Ley 35/2006, de 28 de noviembre, del Impuesto sobre la Renta de las Personas Físicas y de modificación parcial de las leyes de los Impuestos sobre Sociedades, sobre la Renta de no Residentes y sobre el Patrimonio (BOE núm. 285, del 29).

${ }^{17}$ Dispone el artículo 99 de la Ley, que se ocupa de la obligación de practicar pagos a cuenta: 1. En el Impuesto sobre la Renta de las Personas Físicas, los pagos a cuenta que, en todo caso, tendrán la consideración de deuda tributaria, podrán consistir en: a) Retenciones. b) Ingresos a cuenta. c) Pagos fraccionados. 
trabando. En materia de procedimiento los trámites a veces son tan prolijos que avalan igualmente la conveniencia de una ley especial.

En cuanto a las causas de justificación ${ }^{18}$, el estado de necesidad a que algunos aluden no es posible, pues entre una colisión de intereses públicos y privados, o entre el deber de pagar a un acreedor privado o al erario, pese a la amplitud de la fórmula del artículo 20.5. ${ }^{\circ}$ nunca podrá hablarse de causación de un mal menor o igual, por tener, en principio, siempre la primacía los intereses y deberes públicos. Podría estimarse en algunos supuestos, como dedicar el dinero a comprar medicinas, por enfermedad grave.

La imposibilidad de efectuar el pago del impuesto por carecer de medios para ello habrá de reconducirse, en su caso, a los supuestos de exclusión de la acción. Quien declara correctamente a Hacienda sus deudas tributarias y no puede pagar, hay que entender que no comete delito, pues no hay engaño, aunque la falta de pago ha de ser consecuencia de una imposibilidad material de poder hacerlo, y siempre que la situación de insolvencia no la haya buscado de propósito el sujeto obligado tributariamente.

Sólo son posibles las conductas dolosas, siendo suficiente el dolo eventual. Sin embargo, el sistema tributario resulta con frecuencia tan complicado para el contribuyente que solamente especialistas en la materia son capaces de entender los modelos de impresos que debe cumplimentar el obligado tributario. Esto nos lleva al tema del error, donde son perfectamente concebibles tanto el error de tipo como el de prohibición, vencible o invencible ${ }^{19}$.

\section{Presentación de declaraciones o autoliquidaciones}

Dispone el párrafo segundo del artículo 305.1: «La mera presentación de declaraciones o autoliquidaciones no excluye la defraudación, cuando ésta se acredite por otros hechos».

El descubrimiento del fraude tributario puede llevarse a cabo a través de cualquier procedimiento. Se pretende evitar la interpretación que pueda darse a que no se comete fraude por la simple presentación de declaraciones o autoliquidaciones.

\footnotetext{
${ }^{18}$ Pérez Martínez, D., «Causas de justificación. La regularización tributaria», en Manual de Delitos contra la Hacienda Pública, cit., págs. 185 y ss.

${ }^{19}$ Vid. Ayala Gómez, El delito de defraudación tributaria, Madrid, 1988, págs. 289 y ss.
} 


\section{Cuantía del fraude y periodo evaluable}

En el apartado 1 del artículo 305 se establece que la cuantía del fraude ha de superar los ciento veinte mil euros. En cuanto al periodo para determinar la cuantía dispone el apartado 2 de este artículo:

"A los efectos de determinar la cuantía mencionada en el apartado anterior: a) Si se trata de tributos, retenciones, ingresos a cuenta o devoluciones, periódicos o de declaración periódica, se estará a lo defraudado en cada período impositivo o de declaración, y si éstos son inferiores a doce meses, el importe de lo defraudado se referirá al año natural. No obstante lo anterior, en los casos en los que la defraudación se lleve a cabo en el seno de una organización o grupo criminal, o por personas o entidades que actúen bajo la apariencia de una actividad económica real sin desarrollarla de forma efectiva, el delito será perseguible desde el mismo momento en que se alcance la cantidad fijada en el apartado 1. b) En los demás supuestos, la cuantía se entenderá referida a cada uno de los distintos conceptos por los que un hecho imponible sea susceptible de liquidación».

En el apartado a) se contemplan dos supuestos: 1. El periodo impositivo o de declaración o si son inferiores a doce meses el año natural. 2. Que la defraudación se cometa en el seno de una organización o grupo criminal $^{20} \ldots$ en cuyo caso el delito tiene lugar cuando la cantidad defraudada supere los ciento veinte mil euros, sin necesidad de que transcurra el año natural.

En el apartado b) se recogen los demás supuestos en los que el hecho punible sea susceptible de liquidación, como puede ser en la venta de un inmueble.

En el texto se contemplan varias situaciones diferentes, sin ningún tipo de conexión a efectos del delito, por lo que no cabe acumular las defraudaciones de dos o más supuestos a fin de computar una cifra que supere los ciento veinte mil euros.

Tampoco cabe estimar aquí el delito continuado, sobre la base de la cantidad total defraudada porque al ser inferior la infracción es administrativa y no penal. Lo mismo hay que decir con referencia al período temporal de cada uno de los tributos, pues no son acumulables dentro de cada tributo, ni entre ellos. Por otra parte, y frente a la diversidad de tributos que pueden proceder de la Hacienda estatal, autonómica, foral o local, hay que mantener el mismo criterio, son

${ }^{20}$ Sobre lo que ha de entender por organización o grupo criminal, vid. artículos 570 bis y 570 ter del C.p. 
totalmente independientes, sin ningún tipo de acumulación posible entre unos y otros ${ }^{21}$.

En los supuestos en los que la defraudación se lleve a cabo en el seno de una organización o grupo criminal... es posible la comisión de dos o más delitos dentro del año natural, pudiendo apreciarse continuidad delictiva. La misma situación para los supuestos del apartado b).

No es aplicable aquí lo previsto en el párrafo primero del artículo 74.1 del C.p., en cuanto a que «si se tratare de infracciones contra el patrimonio se impondrá la pena teniendo en cuenta el perjuicio total causado». Tampoco técnicamente los delitos contra la Hacienda Pública son delitos contra el patrimonio en sí, al quedar fuera del Título XIII del Libro II del C.p.

La determinación de la cuantía no resulta fácil en muchos casos. El Juez no tiene por qué ajustarse a la cantidad defraudada que le suministre la Administración, pues corresponde a aquél decidir si hay motivos racionales de criminalidad e iniciar o no un procedimiento penal $^{22}$.

Con respecto a lo que haya de entenderse por cuota defraudada hay que tener en cuenta lo que disponen los arts. 56 y 58 de la LGT. El primero se ocupa de la cuota tributaria y recoge: «1. La cuota íntegra se determinará: a) Aplicando el tipo de gravamen a la base liquidable. b) Según cantidad fija señalada al efecto».

Dispone el artículo 58: «1. La deuda tributaria estará constituida por la cuota o cantidad a ingresar que resulte de la obligación tributaria principal o de las obligaciones de realizar pagos a cuenta. 2. Además, la deuda tributaria estará integrada, en su caso, por: a) El interés de demora. b) Los recargos por declaración extemporánea. c) Los recargos del período ejecutivo. d) Los recargos exigibles legalmente sobre las bases o las cuotas, a favor del Tesoro o de otros entes públicos».

La consumación. Sobre esta cuestión ya nos hemos pronunciado en el primer apartado de este trabajo. Depende de que la regulación tributaria se considere como excusa absolutoria o como exclusión de la tipicidad.

Se apuntó más arriba que sujeto activo del delito es el obligado al pago que realiza la conducta típica de la defraudación. En cuanto a la participación, hay que tener en cuenta a quienes actúan en represen-

${ }^{21}$ Vid. Boix Reig, J. y Mira Benavent, J., Los delitos contra la Hacienda Pública y la Seguridad Social, Valencia, 2000, págs. 70 y ss.

${ }^{22}$ Vid. MarTínez-Buján Pérez, ob. cit., pág. 554. 
tación del obligado ${ }^{23}$. En los supuestos en que el sujeto carezca de capacidad de obrar deben considerarse autores sus representantes legales. Si el obligado tributariamente es una persona jurídica, habrá que tener en cuenta lo que dispone el artículo 31 del C.p., que sería de aplicación en los supuestos en que se actúe en nombre de otro.

Es preciso poner en claro, en primer término, lo que ha de entenderse por «autor material». Ha de considerarse como equivalente a "autor en sentido estricto». Autor es aquel que realiza la acción u omisión constitutiva del tipo del injusto. Ahora bien, si quien defrauda es un ente colectivo impersonal, es difícil imaginar cómo puede ser «autor material» en tal supuesto una persona física, lo que se resolverá de acuerdo con el artículo 31 .

Tropezamos con el difícil problema de los asesores fiscales, que a su vez operan con los datos que les proporcionan la empresa, ente o sociedad. Si acudimos a quien proporciona estos datos, buscando al menos un autor inmediato, podremos encontramos con los administradores. Las personas que colaboran en la comisión del delito, con el obligado tributario, pueden responder a título de inductor, de cooperador necesario o cómplice; a veces podrán ser los propios asesores fiscales ${ }^{24}$.

En el tema de la participación hay que tener en cuenta el deber de colaboración con la Administración tributaria, que lleva incluso al problema del secreto bancario. Establece el párrafo primero del artículo 93.3 de la LGT: «El incumplimiento de las obligaciones establecidas en este artículo no podrá ampararse en el secreto bancario».

Con respecto a las personas jurídicas, habría de interpretarse que son responsables criminalmente todos aquellos que tengan conocimiento de los hechos e intervengan en ellos (o no los eviten pudiendo hacerlo), bien ordenando no pagar los impuestos que se adeudan o mandando que se ingresen cantidades inferiores a las realmente adeudadas. Podría plantearse la aplicación de una atenuante por analogía de miedo insuperable o de estado de necesidad como causas de

${ }^{23}$ Vid. Silva SÁNCHEZ, ob. cit., págs. 53 y ss. La Ley General Tributaria se ocupa de la capacidad de obrar en el orden tributario en sus artículos 44 y siguientes: capacidad de obrar (artículo 44), representación legal (artículo 45) y representación voluntaria (artículo 46). Dispone el apartado 1 de este último: «Los obligados tributarios con capacidad de obrar podrán actuar por medio de representante, que podrá ser un asesor fiscal, con el que se entenderán las sucesivas actuaciones administrativas, salvo que se haga manifestación expresa en contrario».

${ }^{24}$ Merino Jara, I. y Serrano González DE Murillo, J. L., «La responsabilidad del asesor fiscal en el ejercicio de su actividad profesional», en $R D F H P, 1994$, págs. 993 y ss. Silva SÁnCHEZ, ob. cit., págs. 79 y ss. 
no exigibilidad de una conducta distinta para excusar al empleado que por temor a perder su cargo o puesto de trabajo coopera a estos hechos.

\section{Defraudación contra la Hacienda de la Unión Europea}

La Ley 2012 deroga los artículos 309, 627 y 628 del Código penal, que se ocupaban de estas defraudaciones como delitos o faltas ${ }^{25}$.

El legislador es más riguroso en estas infracciones. En las defraudaciones contra la Hacienda Pública estatal (artículo 305.1) solo se castiga el fraude superior a ciento veinte mil euros, en otro caso es infracción administrativa. En el caso de la Hacienda de la Unión Europea el límite son cincuenta mil euros, y, además, contempla el supuesto en que se superen los cuatro mil pero no se rebasen los cincuenta mil. Ahora el sujeto pasivo del delito es la Unión Europea ${ }^{26}$.

\section{Defraudaciones superiores a cincuenta mil euros}

"Las mismas penas se impondrán cuando las conductas descritas en el apartado 1 de este artículo se cometan contra la Hacienda de la Unión Europea, siempre que la cuantía defraudada excediera de cincuenta mil euros en el plazo de un año natural. No obstante lo anterior, en los casos en los que la defraudación se lleve a cabo en el seno de una organización o grupo criminal, o por personas o entidades que actúen bajo la apariencia de una actividad económica real sin desarrollarla de forma efectiva, el delito será perseguible desde el mismo momento en que se alcance la cantidad fijada en este apartado» (artículo 305.3, párrafo primero).

Pena: Prisión de uno a cinco años y multa del tanto al séxtuplo de la citada cuantía. Además, se impondrá al responsable la pérdida de la posibilidad de obtener subvenciones o ayudas públicas y del derecho a gozar de los beneficios o incentivos fiscales o de la Seguridad Social durante el período de tres a seis años.

Cuantía de la defraudación. La cantidad defraudada tiene que exceder de cincuenta mil euros. Este supuesto se agrava con respecto al fraude a la Hacienda Pública estatal, autonómica, foral o local, donde la cantidad ha de superar los ciento veinte mil euros.

${ }^{25}$ SAmpol Pucurrul, M. y Redondo Andrés, I., «Protección de los intereses financieros de la Unión Europea en el Código penal», págs. 55 y ss.

${ }^{26}$ Vid. IbáÑez Mansilla, S. y Bosch CholbI, J. L., "La protección penal de la Hacienda Comunitaria», en Crónica Tributaria, núm. 86, 1998, págs. 75 y ss. 
Periodo. Se hace referencia expresa al año natural y se reitera el texto del inciso segundo del apartado 2 del artículo 305 respecto de los supuestos en los que la defraudación se lleva a cabo en el seno de una organización o grupo criminal...

Defraudaciones superiores a cuatro mil euros que no superen los cincuenta mil

Si la cuantía defraudada no superase los cincuenta mil euros, pero excediere de cuatro mil, se impondrá una pena de prisión de tres meses a un año o multa del tanto al triplo de la citada cuantía y la pérdida de la posibilidad de obtener subvenciones o ayudas públicas y del derecho a gozar de los beneficios o incentivos fiscales o de la Seguridad Social durante el período de seis meses a dos años (artículo 305.3, párrafo segundo).

La pena es alternativa. Puede ser prisión de tres meses a un año o multa del tanto al triplo de la cuantía defraudada.

\section{Regularización tributaria}

"Se considerará regularizada la situación tributaria cuando se haya procedido por el obligado tributario al completo reconocimiento y pago de la deuda tributaria, antes de que por la Administración Tributaria se le haya notificado el inicio de actuaciones de comprobación o investigación tendentes a la determinación de las deudas tributarias objeto de la regularización o, en el caso de que tales actuaciones no se hubieran producido, antes de que el Ministerio Fiscal, el Abogado del Estado o el representante procesal de la Administración autonómica, foral o local de que se trate, interponga querella o denuncia contra aquél dirigida, o antes de que el Ministerio Fiscal o el Juez de Instrucción realicen actuaciones que le permitan tener conocimiento formal de la iniciación de diligencias» (artículo 305.4, párrafo primero).

La regularización tributaria que conlleva a la exención de responsabilidad penal, según se recoge en el inciso último del artículo 305.1, se contempla en tres supuestos:

a) Cuando el obligado tributario reconozca y pague la deuda antes de que la Administración tributaria le notifique el inicio de las actuaciones para determinar la deuda tributaria objeto de la regulación. El plazo a tener en cuenta será el de la fecha en la que el interesado recibe formalmente la notificación, que ha de ser antes de haber 
transcurrido cuatro años que es el plazo en el que prescribe la deuda tributaria.

b) Si no ha tenido lugar el procedimiento anterior, el defraudador tiene que haber regulado su situación antes de que el Ministerio Fiscal, el Abogado del Estado o el representante procesal de la Administración autonómica, foral o local interponga querella o denuncia contra el obligado tributario. El plazo para la interposición de denuncia o querella es de cinco años. Comenzará a contar en la fecha de consumación del delito y terminará a los cinco años que es cuando prescribe el delito, pues la pena de prisión es de uno a cinco años ${ }^{27}$.

Sobre la problemática que se plantea en la doctrina respecto de si el fraude tributario (artículo 305.1) es o no una excusa absolutoria, lo que afecta tanto a la consumación del delito como al comienzo del plazo de prescripción nos remitimos a lo que se expuso al comienzo de este trabajo.

c) Antes de que el Ministerio Fiscal o el Juez de Instrucción realicen actuaciones que le permitan tener conocimiento formal de la iniciación de diligencias.

Otros efectos de la regularización

Se recogen a continuación diversas situaciones que afectan a la regularización.

1. Satisfacción de la deuda tributaria una vez prescrita la vía administrativa.

"Los efectos de la regularización prevista en el párrafo anterior resultarán aplicables cuando se satisfagan deudas tributarias una vez prescrito el derecho de la Administración a su determinación en vía administrativa» (artículo 305.4, párrafo segundo).

2. La regularización impide la persecución de irregularidades contables y falsedades instrumentales previas.

«La regularización por el obligado tributario de su situación tributaria impedirá que se le persiga por las posibles irregularidades contables u otras falsedades instrumentales que, exclusivamente en relación a la deuda tributaria objeto de regularización, el mismo pudiera haber come-

${ }^{27}$ De acuerdo con lo establecido en el párrafo quinto del artículo 131.1 del C.p. este delito prescribe a los cinco años. En los supuestos agravados previstos en el art. 305 bis. 1 y 307 bis. 1 la pena de prisión es de dos a seis años; la prescripción del delito sería a los diez. 
tido con carácter previo a la regularización de su situación tributaria» (artículo 305.4, párrafo tercero).

En estos supuestos se consideran absorbidas con la regularización otras irregularidades, o incluso falsedades instrumentales que pudieran haberse cometido con anterioridad a la regulación.

\section{Liquidación tributaria y presunto delito fiscal}

En el apartado 5 del artículo 305 se contemplan tres situaciones que permiten continuar los trámites para el cobro de la deuda tributaria por la Administración, cuando aparezcan indicios de la comisión de un delito fiscal, así como cuando ya se hubiera iniciado un procedimiento penal.

a) Liquidaciones tributarias cuando aparezcan indicios de comisión de delito.

"Cuando la Administración Tributaria apreciare indicios de haberse cometido un delito contra la Hacienda Pública, podrá liquidar de forma separada, por una parte los conceptos y cuantías que no se encuentren vinculados con el posible delito contra la Hacienda Pública, y por otra, los que se encuentren vinculados con el posible delito contra la Hacienda Pública» (artículo 305.5, párrafo primero).

En estos supuestos es potestativo para la Administración Tributaria liquidar de forma separada los conceptos y cuantías que no se encuentren vinculados a un presunto delito contra la Hacienda Pública de aquellos que pueden estar vinculados. De esta forma se impide que un procedimiento penal paralice el cobro de la cantidad no satisfecha. En no pocas ocasiones será difícil distinguir entre los conceptos y cuantías que están o no vinculados al delito.

b) Tramitación de la liquidación de conceptos y cuantías vinculadas a un presunto delito fiscal

"La liquidación indicada en primer lugar en el párrafo anterior seguirá la tramitación ordinaria y se sujetará al régimen de recursos propios de toda liquidación tributaria. Y la liquidación que en su caso derive de aquellos conceptos y cuantías que se encuentren vinculados con el posible delito contra la Hacienda Pública seguirá la tramitación que al efecto establezca la normativa tributaria, sin perjuicio de que finalmente se ajuste a lo que se decida en el proceso penal» (artículo 305.5, párrafo segundo). 
La tramitación en estos supuestos será la establecida en la legislación tributaria, sin perjuicio de que al final se ajuste a lo que se resuelva en el proceso penal.

c) Cobro de la deuda tributaria cuando exista un procedimiento penal por delito.

«La existencia del procedimiento penal por delito contra la Hacienda Pública no paralizará la acción de cobro de la deuda tributaria. Por parte de la Administración Tributaria podrán iniciarse las actuaciones dirigidas al cobro, salvo que el Juez, de oficio o a instancia de parte, hubiere acordado la suspensión de las actuaciones de ejecución, previa prestación de garantía. Si no se pudiese prestar garantía en todo o en parte, excepcionalmente el Juez podrá acordar la suspensión con dispensa total o parcial de garantías si apreciare que la ejecución pudiese ocasionar daños irreparables o de muy difícil reparación» (artículo 305.5, párrafo tercero).

En los dos apartados anteriores se contemplan supuestos indiciarios, es decir posibles delitos contra la Hacienda Pública. Ahora se avanza un poco más y se regula el cobro de la deuda tributaria cuando ya se ha iniciado un procedimiento penal. También aquí es potestativo de la administración tributaria iniciar o no las actuaciones encaminadas al cobro de la deuda tributaria. Sin embargo, el Juez puede suspender tales actuaciones siempre que el obligado al pago haya prestado garantía. No obstante, en el inciso final de este párrafo se contempla la posibilidad de que quien deba prestar la garantía no pueda hacerlo en todo o en parte.

\section{Supuestos atenuados}

Se prevé la posibilidad de rebajar la pena en uno o dos grados.

«Los Jueces y Tribunales podrán imponer al obligado tributario o al autor del delito la pena inferior en uno o dos grados, siempre que, antes de que transcurran dos meses desde la citación judicial como imputado satisfaga la deuda tributaria y reconozca judicialmente los hechos. Lo anterior será igualmente aplicable respecto de otros partícipes en el delito distintos del obligado tributario o del autor del delito, cuando colaboren activamente para la obtención de pruebas decisivas para la identificación o captura de otros responsables, para el completo esclarecimiento de los hechos delictivos o para la averiguación del patrimonio del obligado tributario o de otros responsables del delito» (artículo 305.6).

Se contemplan dos supuestos: 
a) Obligado tributario o autor del delito. Han de hacer efectiva la deuda tributaria y reconocer judicialmente los hechos antes de transcurrido dos meses desde la citación judicial como imputados.

Los efectos son los mismos que los de una atenuante muy cualifi$\mathrm{cada}^{28}$. De no existir este precepto sería de aplicación la atenuante $5 .^{\mathrm{a}}$ del artículo 21 (reparación del daño).

b) Otros partícipes en el delito. Estos han de colaborar con la Administración de Justicia en la identificación y captura de otros responsables, en el esclarecimiento de los hechos o en la averiguación del patrimonio del obligado tributario o de otros responsables del delito ${ }^{29}$.

\section{Ejecución de la pena de multa y responsabilidad civil}

"En los procedimientos por el delito contemplado en este artículo, para la ejecución de la pena de multa y la responsabilidad civil, que comprenderá el importe de la deuda tributaria que la Administración Tributaria no haya liquidado por prescripción u otra causa legal en los términos previstos en la Ley 58/2003, General Tributaria, de 17 de diciembre, incluidos sus intereses de demora, los Jueces y Tribunales recabarán el auxilio de los servicios de la Administración Tributaria que las exigirá por el procedimiento administrativo de apremio en los términos establecidos en la citada Ley» (artículo 305.7).

En los supuestos de condena por delito fiscal son los Jueces los que deciden sobre la ejecución de la pena de multa y responsabilidad civil, y no la Administración Tributaria, sin perjuicio de que recaben en auxilio de esta.

\section{Supuestos agravados}

Se contemplan tres casos en los que se eleva la pena de prisión, así como el límite inferior de la multa. La prisión prevista en el artículo 305 que es de uno a cinco años, pasa a ser de dos a seis, y la multa del tanto al séxtuplo de la cuota defraudada pasa a ser del doble al séxtuplo. Dispone el artículo 305 bis:

1. El delito contra la Hacienda Pública será castigado con la pena de prisión de dos a seis años y multa del doble al séxtuplo de la cuota

${ }^{28}$ Vid. artículo 66.1,2. ${ }^{\text {a }}$ del C.p.

${ }^{29}$ En el artículo 376 del C.p. se rebaja la pena en uno o dos grados para los arrepentidos relacionados con delitos de tráfico ilegal de estupefacientes. 
defraudada cuando la defraudación se cometiere concurriendo alguna de las circunstancias siguientes:

a) «Que la cuantía de la cuota defraudada exceda de seiscientos mil euros».

Esta cantidad, que puede parecer muy elevada, en realidad es un supuesto privilegiado. Si se compara, por ejemplo, con la estafa, resulta que la pena es la misma, de uno a seis años de prisión, si la cuantía supera los cincuenta mil euros ${ }^{30}$, mientras que en el delito contra la Hacienda Pública se han de superar los seiscientos mil euros.

b) «Que la defraudación se haya cometido en el seno de una organización o de un grupo criminal».

Sobre lo que ha de entenderse por organización o grupo criminal hay que recurrir al contenido de los artículos 570 bis y 570 ter del Código penal.

c) «Que la utilización de personas físicas o jurídicas o entes sin personalidad jurídica interpuestos, negocios o instrumentos fiduciarios o paraísos fiscales o territorios de nula tributación oculte o dificulte la determinación de la identidad del obligado tributario o del responsable del delito, la determinación de la cuantía defraudada o del patrimonio del obligado tributario o del responsable del delito».

Se contemplan aquí entramados muy complejos que dificultan la posibilidad de identificar al obligado tributario, autores del delito, $\mathrm{u}$ otros participantes, así como la cuantía del fraude. Hay que tener en cuenta que los procedimientos penales tropiezan con muchas dificultades, son costosos y lentos, por lo que con frecuencia no se inician o terminan sin éxito. Hay que recordar los paraísos fiscales ${ }^{31}$.

\section{Remisión al artículo 305}

"A los supuestos descritos en el presente artículo les serán de aplicación todas las restantes previsiones contenidas en el artículo 305.

En estos casos, además de las penas señaladas, se impondrá al responsable la pérdida de la posibilidad de obtener subvenciones o ayudas

${ }^{30}$ Según el artículo 250.1 del C.p. «El delito de estafa será castigado con las penas de prisión de uno a seis años y multa de seis a doce meses... 5 . $^{\circ}$ Cuando el valor de la defraudación supere los cincuenta mil euros».

${ }^{31}$ La Ley 36/2006, de 29 noviembre (BOE núm. 286 del 30), de medidas para la prevención del fraude fiscal. En su disposición adicional primera se ocupa de la definición de paraíso fiscal. 
públicas y del derecho a gozar de los beneficios o incentivos fiscales o de la Seguridad Social durante el período de cuatro a ocho años» (artículo 305 bis.2).

La remisión a las previsiones del artículo 305 comprenden, entre otras, la exención de responsabilidad criminal prevista en el apartado 4 , en relación con el inciso final del apartado 1.

\section{Defraudación de los presupuestos generales de la Unión Europea y otros administrados por ésta en cuantía superior a cincuenta mil euros}

Se castiga al que "por acción u omisión defraude a los presupuestos generales de la Unión Europea u otros administrados por ésta, en cuantía superior a cincuenta mil euros, eludiendo, fuera de los casos contemplados en el apartado 3 del artículo 305, el pago de cantidades que se deban ingresar, dando a los fondos obtenidos una aplicación distinta de aquella a que estuvieren destinados u obteniendo indebidamente fondos falseando las condiciones requeridas para su concesión u ocultando las que la hubieran impedido» (artículo 306, párrafo primero).

Pena: Prisión de uno a cinco años y multa del tanto al séxtuplo de la citada cuantía.

Fraude por cuantía superior a cuatro mil euros y que no supere los cincuenta mil

Si la cuantía defraudada o aplicada indebidamente no superase los cincuenta mil euros, pero excediere de cuatro mil» (artículo 306 párrafo segundo).

Pena: Prisión de tres meses a un año o multa del tanto al triplo de la citada cuantía y la pérdida de la posibilidad de obtener subvenciones o ayudas públicas y del derecho a gozar de los beneficios o incentivos fiscales o de la Seguridad Social durante el período de seis meses a dos años.

\section{DELITOS CONTRA LA SEGURIDAD SOCIAL}

\section{Tipo básico}

Se recoge en el párrafo primero del artículo 307.1, donde se castiga al que «por acción u omisión, defraude a la Seguridad Social eludiendo el pago de las cuotas de ésta y conceptos de recaudación con- 
junta, obteniendo indebidamente devoluciones de las mismas o disfrutando de deducciones por cualquier concepto asimismo de forma indebida, siempre que la cuantía de las cuotas defraudadas o de las devoluciones o deducciones indebidas exceda de cincuenta mil euros ... salvo que hubiera regularizado su situación en la Seguridad Social en los términos del apartado 3 del presente artículo».

Pena: Prisión de uno a cinco años y multa del tanto al séxtuplo de la citada cuantía. Además se impondrá al responsable la pérdida de la posibilidad de obtener subvenciones o ayudas públicas y del derecho a gozar de los beneficios o incentivos fiscales o de la Seguridad Social durante el periodo de tres a seis meses.

Hay un endurecimiento de la Ley ${ }^{32}$.

Antes de la reforma de estos delitos, en diciembre de 2012, la cuota defraudada debía superar los ciento veinte mil euros, como en la defraudación contra la Hacienda Pública, que se mantiene. Ahora son cincuenta mil euros.

«La mera presentación de los documentos de cotización no excluye la defraudación, cuando ésta se acredite por otros hechos» (artículo 307.1, párrafo segundo ${ }^{33}$.

Se incluye este párrafo para evitar ciertas formas de engaño ${ }^{34}$.

El bien jurídico protegido es el patrimonio de la Seguridad Social.

Sujeto activo es el obligado que elude el pago realizando la conducta típica de defraudación. Sujeto pasivo es la Seguridad Social.

${ }^{32}$ Recoge párrafo primero del apartado IV del preámbulo de la Ley de 2012: «... La reducción de la cuantía del tipo delictivo permite que sean objeto de punibilidad penal hechos que actualmente sólo son sancionables administrativamente y que son objeto de un contundente reproche social en momentos de especial dificultad económica en el ámbito empresarial como los actuales».

${ }^{33}$ Dispone el párrafo segundo del apartado IV del preámbulo de la Ley: «En la práctica se dan supuestos en los que se interpreta que no existe delito contra la Seguridad Social por el mero hecho de que se hayan presentado los documentos de cotización, sin entrar a valorar si son veraces y completos. También es frecuente que en los supuestos de defraudación en los que intervienen personas interpuestas, precisamente, la presentación de documentos de cotización aparentemente correctos forma parte del engaño. Por ello, se ha añadido un último inciso...».

${ }^{34}$ Recoge el párrafo segundo del apartado IV del preámbulo de la Ley de reforma: «En la práctica se dan supuestos en los que se interpreta que no existe delito contra la Seguridad Social por el mero hecho de que se hayan presentado los documentos de cotización, sin entrar a valorar si son veraces y completos. También es frecuente que en los supuestos de defraudación en los que intervienen personas interpuestas, precisamente, la presentación de documentos de cotización aparentemente correctos forman parte del engaño». 
Los supuestos que se contemplan son la elusión del pago de las cuotas de la Seguridad Social y concepto de recaudación conjunta, la obtención indebida de devoluciones y el disfrute indebido de deducciones. Lo mismo que sucede en el fraude tributario no caben las conductas imprudentes, siendo preciso el ánimo de lucro que se deduce de la finalidad defraudatoria. Sobre las cuestiones generales relativas a este delito me remito a lo expuesto anteriormente para el fraude tributario.

«A los efectos de determinar la cuantía mencionada en el apartado anterior, se estará al importe total defraudado durante cuatro años naturales» (artículo 307.2).

\section{Regularización de la deuda y exención de responsabilidad penal}

«Se considerará regularizada la situación ante la Seguridad Social cuando se haya procedido por el obligado frente a la Seguridad Social al completo reconocimiento y pago de la deuda antes de que se le haya notificado la iniciación de actuaciones inspectoras dirigidas a la determinación de dichas deudas o, en caso de que tales actuaciones no se hubieran producido, antes de que el Ministerio Fiscal o el Letrado de la Seguridad Social interponga querella o denuncia contra aquél dirigida o antes de que el Ministerio Fiscal o el Juez de Instrucción realicen actuaciones que le permitan tener conocimiento formal de la iniciación de diligencias» (artículo 307.3, párrafo primero).

Estamos ante una situación similar a la del artículo 305.4 que se ocupa de la regularización en los delitos contra la Hacienda Pública.

"Asimismo, los efectos de la regularización prevista en el párrafo anterior, resultarán aplicables cuando se satisfagan deudas ante la Seguridad Social una vez prescrito el derecho de la Administración a su determinación en vía administrativa» (artículo 307.3, párrafo segundo).

En las infracciones fiscales la prescripción administrativa es a los cuatro años, en la penal a los cinco -en algunos supuestos a los diez ${ }^{35}$.

La regularización impide la persecución de irregularidades contables o falsedades instrumentales previas

${ }^{35}$ Vid. artículo 131.1 del C.p. y 66 de la LGT en apartado VII. 
"La regularización de la situación ante la Seguridad Social impedirá que a dicho sujeto se le persiga por las posibles irregularidades contables $u$ otras falsedades instrumentales que, exclusivamente en relación a la deuda objeto de regularización, el mismo pudiera haber cometido con carácter previo a la regularización de su situación» (artículo 307.3, párrafo tercero $)^{36}$.

\section{Liquidación y cobro de la deuda mediante procedimiento penal por delito}

"La existencia de un procedimiento penal por delito contra la Seguridad Social no paralizará el procedimiento administrativo para la liquidación y cobro de la deuda contraída con la Seguridad Social, salvo que el Juez lo acuerde previa prestación de garantía. En el caso de que no se pudiese prestar garantía en todo o en parte, el Juez, con carácter excepcional, podrá acordar la suspensión con dispensa total o parcial de las garantías, en el caso de que apreciara que la ejecución pudiera ocasionar daños irreparables o de muy difícil reparación. La liquidación administrativa se ajustará finalmente a lo que se decida en el proceso penal» (artículo 307.4).

La situación es similar a la que se contempla en el párrafo tercero del artículo 305.5 en el fraude a la Hacienda Pública.

\section{Supuestos atenuados}

Se prevé la posibilidad de rebajar la pena en uno o dos grados

"Los Jueces y Tribunales podrán imponer al obligado frente a la Seguridad Social o al autor del delito la pena inferior en uno o dos grados, siempre que, antes de que transcurran dos meses desde la citación judicial como imputado, satisfaga la deuda con la Seguridad Social y reconozca judicialmente los hechos. Lo anterior será igualmente aplicable respecto de otros partícipes en el delito distintos del deudor a la Seguridad Social o del autor del delito, cuando colaboren activamente para la obtención de pruebas decisivas para la identificación o captura de otros responsables, para el completo esclarecimiento de los hechos delictivos o para la averiguación del patrimonio del obligado frente a la Seguridad Social o de otros responsables del delito» (artículo 307.5).

La situación es similar a la del artículo 305.6 para las defraudaciones contra la Hacienda Pública. También allí está previsto rebajar la pena en uno o dos grados.

${ }^{36}$ Vid. Bajo Fernández, M. y Bacigalupo Sagesse, S., Delitos contra la Hacienda Pública, Madrid, 2000, págs. 104 y ss. 


\section{Ejecución de la pena de multa y responsabilidad civil}

«En los procedimientos por el delito contemplado en este artículo, para la ejecución de la pena de multa y la responsabilidad civil, que comprenderá el importe de la deuda frente a la Seguridad Social que la Administración no haya liquidado por prescripción u otra causa legal, incluidos sus intereses de demora, los Jueces y Tribunales recabarán el auxilio de los servicios de la Administración de la Seguridad Social que las exigirá por el procedimiento administrativo de apremio» (artículo 307.6).

La situación es parecida a la que se contempla en el artículo 305.7 para las defraudaciones contra la Hacienda Pública, aunque varía la tramitación administrativa.

\section{Supuestos agravados en delitos contra la Seguridad Social}

Tienen lugar «cuando en la comisión del delito concurriera alguna de las siguientes circunstancias:

a) Que la cuantía de las cuotas defraudadas o de las devoluciones o deducciones indebidas exceda de ciento veinte mil euros.

b) Que la defraudación se haya cometido en el seno de una organización o de un grupo criminal.

c) Que la utilización de personas físicas o jurídicas o entes sin personalidad jurídica interpuestos, negocios o instrumentos fiduciarios o paraísos fiscales o territorios de nula tributación oculte o dificulte la determinación de la identidad del obligado frente a la Seguridad Social o del responsable del delito, la determinación de la cuantía defraudada o del patrimonio del obligado frente a la Seguridad Social o del responsable del delito» (artículo 307 bis.1).

Pena: Prisión de dos a seis años y multa del doble al séxtuplo de la cuantía. Además se impondrá al responsable la pérdida de la posibilidad de obtener subvenciones o ayudas públicas y del derecho a gozar de los beneficios o incentivos fiscales o de la Seguridad Social durante el período de cuatro a ocho años.

La situación de las letras b) y c) es similar al contenido del artículo 305 bis. 1 para los delitos contra la Hacienda Pública. En el apartado a) se eleva la pena cuando la cuantía de las cuotas defraudadas o de las deducciones o devoluciones indebidas exceda de ciento veinte mil euros, mientras que en los delitos contra la Hacienda Pública la cuantía de la deuda defraudada ha de exceder de seiscientos mil euros (artículo 305 bis.1.a). 


\section{Remisión al artículo 307}

"A los supuestos descritos en el presente artículo le serán de aplicación todas las restantes previsiones contenidas en el artículo 307» (artículo 307 bis.2).

Entre ellas cabe destacar la regularización.

\section{Disfrute de prestaciones del sistema de Seguridad Social por medio de error provocado u ocultación de hechos}

Se castiga a "quien obtenga, para sí o para otro, el disfrute de prestaciones del Sistema de la Seguridad Social, la prolongación indebida del mismo, o facilite a otros su obtención, por medio del error provocado mediante la simulación o tergiversación de hechos, o la ocultación consciente de hechos de los que tenía el deber de informar, causando con ello un perjuicio a la Administración Pública» (artículo 307 ter.1, párrafo primero).

Pena: Prisión de seis meses a tres años. Además, se impondrá al responsable la pérdida de la posibilidad de obtener subvenciones y del derecho a gozar de los beneficios o incentivos fiscales o de la Seguridad Social durante el período de tres a seis años.

Es necesario que se cause perjuicio a la Administración. No se especifica la cuantía, aunque se prevé una atenuación cuando el importe defraudado no revista especial gravedad. La valoración queda al arbitrio del Juez.

\section{Supuestos atenuados}

"Cuando los hechos, a la vista del importe defraudado, de los medios empleados y de las circunstancias personales del autor, no revistan especial gravedad» (artículo 307 ter.1, párrafo segundo).

Queda al arbitrio del Juez estimar cuando concurren estar circunstancias.

Pena: Multa del tanto al séxtuplo de la cantidad defraudada. Además, se impondrá al responsable la pérdida de la posibilidad de obtener subvenciones y del derecho a gozar de los beneficios o incentivos fiscales o de la Seguridad Social durante el período de tres a seis años. 


\section{Supuestos agravados}

"Cuando el valor de las prestaciones fuera superior a cincuenta mil euros o hubiera concurrido cualquiera de las circunstancias a que se refieren las letras b) o c) del apartado 1 del artículo 307 bis» (artículo 307 ter.2).

Pena: Prisión de dos a seis años y multa del tanto al séxtuplo. Además de las penas señaladas, se impondrá al responsable la pérdida de la posibilidad de obtener subvenciones y del derecho a gozar de los beneficios o incentivos fiscales o de la Seguridad Social durante el período de cuatro a ocho años.

\section{Exención de la responsabilidad criminal por el reintegro de la cantidad recibida}

"Quedará exento de responsabilidad criminal en relación con las conductas descritas en los apartados anteriores el que reintegre una cantidad equivalente al valor de la prestación recibida incrementada en un interés anual equivalente al interés legal del dinero aumentado en dos puntos porcentuales, desde el momento en que las percibió, antes de que se le haya notificado la iniciación de actuaciones de inspección y control en relación con las mismas o, en el caso de que tales actuaciones no se hubieran producido, antes de que el Ministerio Fiscal, el Abogado del Estado, el Letrado de la Seguridad Social, o el representante de la Administración autonómica o local de que se trate, interponga querella o denuncia contra aquél dirigida o antes de que el Ministerio Fiscal o el Juez de Instrucción realicen actuaciones que le permitan tener conocimiento formal de la iniciación de diligencias» (artículo 307 ter. 3, párrafo primero).

El reintegro de la cantidad, equivalente al valor de la recibida, se incrementa en dos puntos porcentuales desde que se recibió la prestación.

Nos encontramos ante un supuesto equivalentes a la regulación en las defraudaciones de los artículos arts. 305.4 y 307.3.

\section{Exención de la responsabilidad penal por las falsedades instrumentales previas a la regularización}

"La exención de responsabilidad penal contemplada en el párrafo anterior alcanzará igualmente a dicho sujeto por las posibles falsedades instrumentales que, exclusivamente en relación a las prestaciones defraudadas objeto de reintegro, el mismo pudiera haber cometido con ca- 
rácter previo a la regularización de su situación» (artículo 307 ter.3, párrafo segundo).

Se reitera la misma situación que en los supuestos de regulación en los delitos contra la Hacienda Pública (artículo 305.4 y contra la Seguridad Social (artículo 307.3).

\section{Reintegro de las prestaciones indebidas en los supuestos de existencia de un procedimiento penal}

"La existencia de un procedimiento penal por alguno de los delitos de los apartados 1 y 2 de este artículo, no impedirá que la Administración competente exija el reintegro por vía administrativa de las prestaciones indebidamente obtenidas. El importe que deba ser reintegrado se entenderá fijado provisionalmente por la Administración, y se ajustará después a lo que finalmente se resuelva en el proceso penal» (artículo 307 ter. 4, párrafo primero).

De forma similar a como sucede en los delitos contra la Hacienda Pública (artículo 305.5) y contra la Seguridad Social (artículo 307.4) la existencia de un procedimiento penal no impide que la Administración exija provisionalmente el ingreso de las prestaciones indebidamente obtenidas, aunque la cantidad será la que finalmente se fije en el proceso penal.

En el párrafo segundo se recoge que el procedimiento penal no paraliza las actuaciones para el cobro, salvo que el Juez acuerde la suspensión de la ejecución.

«El procedimiento penal tampoco paralizará la acción de cobro de la Administración competente, que podrá iniciar las actuaciones dirigidas al cobro salvo que el Juez, de oficio o a instancia de parte, hubiere acordado la suspensión de las actuaciones de ejecución previa prestación de garantía. Si no se pudiere prestar garantía en todo o en parte, excepcionalmente el Juez podrá acordar la suspensión con dispensa total o parcial de garantías si apreciare que la ejecución pudiese ocasionar daños irreparables o de muy difícil reparación» (artículo 307 ter. 4, párrafo segundo).

\section{Ejecución de la pena de multa y de la responsabilidad civil}

«En los procedimientos por el delito contemplado en este artículo, para la ejecución de la pena de multa y de la responsabilidad civil, los Jueces y Tribunales recabarán el auxilio de los servicios de la Administración de la Seguridad Social que las exigirá por el procedimiento administrativo de apremio» (artículo 307 ter.5). 
Se trata del auxilio que han de prestar los servicios de la Administración de la Seguridad Social a los Jueces y Tribunales para la ejecución de la pena de multa y responsabilidad civil.

\section{Remisión al artículo 307.5}

"Resultará aplicable a los supuestos regulados en este artículo lo dispuesto en el apartado 5 del artículo 307 del Código Penal» (artículo 307 ter.5). El indicado apartado 5 contempla supuestos atenuados.

Permite al Juez rebajar la pena en uno o dos grados al autor del delito por reconocer y satisfacer la deuda, antes de transcurrir dos meses desde la citación como imputado, y con respecto de otros que hayan participado en la comisión del delito por su colaboración de forma decisiva con la Administración de Justicia para la identificación o captura de otros responsables, esclarecimiento de los hechos o averiguación del patrimonio del obligado. Estamos ante un supuesto de colaboración por arrepentimiento.

\section{FRAUDE Y MALVERSACIÓN DE SUBVENCIONES}

\section{Fraude de subvenciones}

Se castiga al "que obtenga subvenciones o ayudas de las Administraciones Públicas en una cantidad o por un valor superior a ciento veinte mil euros falseando las condiciones requeridas para su concesión u ocultando las que la hubiesen impedido ... salvo que lleve a cabo el reintegro a que se refiere el apartado 5 de este artículo» (artículo 308.1)

Pena: Prisión de uno a cinco años y multa del tanto al séxtuplo de su importe. Además, se impondrá al responsable la pérdida de la posibilidad de obtener subvenciones o ayudas públicas y del derecho a gozar de beneficios o incentivos fiscales o de la Seguridad Social durante un período de tres a seis años.

Se da aquí, por parte del autor, un comportamiento previo falsario, para conseguir de forma ilícita subvenciones que la emparentan con la estafa, pues, aunque de modo explícito no se recoja, existe ánimo de lucro, y mediante los procedimientos falsarios se induce a error al organismo público correspondiente para que se conceda la subvención o desgravación.

Se presentan dificultades para precisar el concepto de «subvención», lo que puede llevar a una cierta inseguridad jurídica. La cues- 
tión resulta problemática no sólo para los penalistas ${ }^{37}$, sino para los especialistas en Derecho financiero y tributario ${ }^{38}$.

Sólo es posible la comisión dolosa, deduciéndose también de los términos empleados por el legislador en el artículo 308.1: «Falseando» u «ocultando». Por esta razón, el error de tipo no podría operar aquí para incriminar formas imprudentes en los supuestos de error vencible.

\section{Malversación de subvenciones}

Se castiga «al que, en el desarrollo de una actividad sufragada total o parcialmente con fondos de las Administraciones públicas los aplique en una cantidad superior a ciento veinte mil euros a fines distintos de aquéllos para los que la subvención o ayuda fue concedida salvo que lleve a cabo el reintegro a que se refiere el apartado 5 de este artículo» (artículo 308.2).

Pena: Prisión de uno a cinco años y multa del tanto al séxtuplo de su importe. Además, se impondrá al responsable la pérdida de la posibilidad de obtener subvenciones o ayudas públicas y del derecho a gozar de beneficios o incentivos fiscales o de la Seguridad Social durante un período de tres a seis años.

\section{Determinación de la cantidad defraudada}

"Para la determinación de la cantidad defraudada se estará al año natural y deberá tratarse de subvenciones o ayudas obtenidas para el fomento de la misma actividad privada subvencionable, aunque procedan de distintas administraciones o entidades públicas» (artículo 308.4).

El cómputo de la cantidad defraudada se determinará sumando todas las que se hayan producido en el año natural.

\section{Reintegro de subvenciones o ayudas y exención de responsabilidad criminal}

En el apartado 1 del artículo 308, como hemos visto, se castiga la obtención de subvenciones o ayudas falseando u ocultando las condi-

${ }^{37}$ Pereña Peinado, I., «El fraude de subvenciones», en Manual de delitos contra la Hacienda Pública, cit., págs. 517 y ss.

38 Vid. Cugat Mauri, M., "El concepto de subvención en los delitos contra la Hacienda Pública», en Revista jurídica de Cataluña, núm. 4, 2008, págs. 1131 y ss. 
ciones requeridas, salvo que se lleve a cabo el reintegro según se recoge en su apartado 5. La misma situación se contempla en la aplicación a fines distintos para las fueron concedidas las subvenciones o ayudas públicas.

Dispone el párrafo primero del artículo 308.5: «Se entenderá realizado el reintegro al que se refieren los apartados 1 y 2 cuando por el perceptor de la subvención o ayuda se proceda a devolver las subvenciones o ayudas indebidamente percibidas o aplicadas, incrementadas en el interés de demora aplicable en materia de subvenciones desde el momento en que las percibió, y se lleve a cabo antes de que se haya notificado la iniciación de actuaciones de comprobación o control en relación con dichas subvenciones o ayudas o, en el caso de que tales actuaciones no se hubieran producido, antes de que el Ministerio Fiscal, el Abogado del Estado o el representante de la Administración autonómica o local de que se trate, interponga querella o denuncia contra aquél dirigida o antes de que el Ministerio Fiscal o el Juez de Instrucción realicen actuaciones que le permitan tener conocimiento formal de la iniciación de diligencias».

El reintegro de las subvenciones indebidamente recibidas o aplicadas han de incrementarse con el interés de demora correspondiente.

El procedimiento para el reintegro es similar al que se recoge para la regularización en los delitos contra la Hacienda Pública (artículo 305.4) y la Seguridad Social (artículo 307.3 y 307 ter.3).

\section{El reintegro impide la persecución de falsedades instrumentales previas}

"El reintegro impedirá que a dicho sujeto se le persiga por las posibles falsedades instrumentales que, exclusivamente en relación a la deuda objeto de regularización, el mismo pudiera haber cometido con carácter previo a la regularización de su situación» (artículo 308.5, párrafo segundo).

Como sucede en la regularización de la situación ante la Seguridad Social (artículo 307.3, párrafo tercero) el delito principal absorbe las irregularidades contables u otras falsedades instrumentales cometidas con carácter previo a la regularización ${ }^{39}$.

39 Vid. Bajo Fernández y Bacigalupo Sagesse, ob. cit., págs. 106 y ss. 


\section{Existencia de procedimiento penal y cobro por la Administración de las subvenciones o ayudas indebidamente aplicadas}

"La existencia de un procedimiento penal por alguno de los delitos de los apartados 1 y 2 de este artículo, no impedirá que la Administración competente exija el reintegro por vía administrativa de las subvenciones o ayudas indebidamente aplicadas. El importe que deba ser reintegrado se entenderá fijado provisionalmente por la Administración, y se ajustará después a lo que finalmente se resuelva en el proceso penal» (artículo 308.6, párrafo primero).

Un procedimiento penal por la obtención de subvenciones o ayudas públicas falseando u ocultando las condiciones requeridas o por aplicación a fines distintos para las que fueron concedidas, no impedirá que la Administración exija la devolución por vía administrativa, aunque de forma provisional, pues finalmente se ajustará a lo que se resuelva en el proceso penal.

\section{Suspensión judicial de la ejecución del cobro iniciado por la Administración}

«El procedimiento penal tampoco paralizará la acción de cobro de la Administración, que podrá iniciar las actuaciones dirigidas al cobro salvo que el Juez, de oficio o a instancia de parte, hubiere acordado la suspensión de las actuaciones de ejecución previa prestación de garantía. Si no se pudiere prestar garantía en todo o en parte, excepcionalmente el Juez podrá acordar la suspensión con dispensa total o parcial de garantías si apreciare que la ejecución pudiese ocasionar daños irreparables o de muy difícil reparación» (artículo 308.6, párrafo segundo).

Aunque el procedimiento penal no paraliza las acciones por parte de la Administración del cobro de las subvenciones o ayudas, el Juez puede suspenderla previa prestación de garantías, aunque puede prescindir si ello ocasionare daños irreparables o de muy difícil reparación.

\section{Supuestos atenuados}

Se prevé la posibilidad de rebajar la pena en uno o dos grados si se procede al reintegro dentro del plazo de dos meses desde que el responsable fue citado judicialmente como imputado (artículo 308.7). También es aplicable a otros partícipes que colaboren con la justicia. 
"Los Jueces y Tribunales podrán imponer al responsable de este delito la pena inferior en uno o dos grados, siempre que, antes de que transcurran dos meses desde la citación judicial como imputado, lleve a cabo el reintegro a que se refiere el apartado 5 y reconozca judicialmente los hechos. Lo anterior será igualmente aplicable respecto de otros partícipes en el delito distintos del obligado al reintegro o del autor del delito, cuando colaboren activamente para la obtención de pruebas decisivas para la identificación o captura de otros responsables, para el completo esclarecimiento de los hechos delictivos o para la averiguación del patrimonio del obligado o del responsable del delito» (artículo 308.7). Estamos ante un supuesto de arrepentimiento ${ }^{40}$.

El texto anterior es prácticamente el mismo que el de los artículos $305.6,307.5$ y 308.7

\section{DEFRAUDACIÓN CONTABLE}

En el artículo 310 se recogen una serie de tipologías que complementan el delito fiscal tipificado en el artículo 305.

\section{Omisión de contabilidad, libros o registros fiscales}

Se castiga al «que estando obligado por ley tributaria a llevar contabilidad mercantil, libros o registros fiscales: a) Incumpla absolutamente dicha obligación en régimen de estimación directa de bases tributarias» (artículo 310, a).

Estamos ante un delito de omisión, en el que no es preciso que se haya ocasionado perjuicio al erario público, ni que el sujeto activo -o un tercero- haya obtenido algún beneficio, ni que necesariamente exista ánimo de lucro. Se tipifican aquí conductas que no dejan de ser meros actos preparatorios, y a veces ni siquiera eso, por un error -vencible o no-, como consecuencia de la complicada mecánica fiscal.

Se trata de un delito que sólo es punible para los supuestos de estimación directa de la base tributaria, no en otros casos, por lo que el legislador ha puesto una limitación que es discutible, ya que también hay deber de registro en algunos supuestos de estimación objetiva. No habrá delito cuando se tengan los libros o registros fiscales obligatorios o se lleve contabilidad. Una contabilidad totalmente desordenada e inoperante a efectos fiscales equivaldría a falta de contabilidad.

${ }^{40}$ Vid. artículo 376 del C.p. 


\section{Doble contabilidad}

Se tipifica aquí el llevar «contabilidades distintas, que, referidas a una misma actividad y ejercicio económico, oculten o simulen la verdadera situación de la empresa» (artículo 310, b).

Los requisitos que se exigen son: 1) llevar contabilidades distintas, que no es necesario se trate de contabilidades formalmente completas, siendo suficiente que no lo sea la presentada a efectos fiscales; 2) que se oculte o simule la verdadera situación de la empresa, y 3) ha de estar referida a la misma actividad y ejercicio económico.

Para que se perfeccione el delito es necesario que la doble contabilidad persiga fines defraudatorios tributarios. La conducta debería ser impune si la doble contabilidad, aun teniendo fines fraudulentos, no llega a utilizarse con tal finalidad, sino que se hace uso de la contabilidad correcta. Tampoco será punible una segunda contabilidad que, aun ocultando o simulando la verdadera situación de la empresa, no persiga una finalidad defraudatoria.

\section{Omisiones o alteraciones contables}

Se dan estos supuestos cuando «no hubiere anotado en los libros obligatorios negocios, actos, operaciones o, en general, transacciones económicas o los hubiere anotado con cifras distintas a las verdaderas» (artículo 310, c).

Se prevén aquí dos conductas, una omisiva, al no hacer anotaciones en los libros obligatorios, y otra consistente en la acción falsaria reflejada en dichos libros con cifras distintas a las verdaderas.

\section{Anotaciones contables ficticias}

Se dan estos supuestos cuando se «hubiere practicado en los libros obligatorios anotaciones contables ficticias» (artículo 310, d).

Nos encontramos ante una falsedad contable que podía perfectamente quedar incluida en el apartado anterior, pues por muy ficticias que sean las anotaciones, es decir, que no responden a realidad alguna, el hecho sigue siendo una falsedad contable; en todo caso podría haberse añadido la referencia ficticia en el párrafo c).

Tanto en estos supuestos de falsedad como en el de omisiones o alteraciones contables, la conducta ha de poner en peligro la efectivi- 
dad de la obligación tributaria. En otro caso habrá alteraciones que darían lugar a una infracción administrativa, pero no penal ${ }^{41}$.

\section{Requisitos del párrafo último del artículo 310}

Se establece en el mismo, para los supuestos de omisiones o falsedades contables, que «la consideración como delito de los supuestos de hecho, a que se refieren los párrafos c) y d) anteriores, requerirá que se hayan omitido las declaraciones tributarias o que las presentadas fueren reflejo de su falsa contabilidad y que la cuantía, en más o menos, de los cargos o abonos omitidos o falseados exceda, sin compensación aritmética entre ellos, de 240.000 euros por cada ejercicio económico».

De lo anterior se desprende que para que se perfeccione el delito previsto en los párrafos e) y d) del artículo 310, además de darse las conductas tipificadas en cada caso, es necesario que concurran los requisitos siguientes: Que se hayan omitido las declaraciones tributarias o que las presentadas fueran reflejo de una falsa contabilidad, y que la cuantía en más o en menos de los cargos o abonos o las falseadas exceda, sin compensación aritmética entre ellas, de 240.000 euros por cada ejercicio económico ${ }^{42}$.

El párrafo último del artículo 310 sitúa en una posición privilegiada las conductas previstas en los párrafos c) y d) respecto del a) y b).

Pena: Prisión de cinco a siete meses para todos los supuestos del artículo 310.

Sólo son posibles los comportamientos dolosos, excluyéndose, por tanto, las formas imprudentes, pues los errores contables por imprudencia son impunes. Es posible la concurrencia de error de tipo o error de prohibición, vencible o invencible, en especial para los supuestos del apartado a), siendo discutible para los otros casos, por lo menos el error de prohibición, en ambos supuestos la conducta es impune.

La consumación para el supuesto a) hay que entender que se da cuando quien estando legalmente obligado por ley tributaria a llevar contabilidad mercantil o libros de registros fiscales no los llevara; en el b), cuando al ser requerido quien llevara la doble contabilidad pre-

\footnotetext{
${ }^{41}$ Vid. Martínez-Buján Pérez, ob. cit., págs. 681 y ss.

${ }^{42}$ Vid. Manzanares Samaniego, J. L., Código penal. II. Parte especial, Granada, 2010, págs. 775 y ss.
} 
sentara la destinada a conseguir la defraudación; en los supuestos de los apartados c) y d), también cuando se presente la contabilidad falseada, o cuando finalice el plazo en que debió presentarse, siendo necesario, además, la concurrencia de los requisitos exigidos en el párrafo último del artículo 310. No es imaginable, en principio, la tentativa.

En cuanto a la participación, teniendo en cuenta que sujeto activo será, según dispone el párrafo primero del artículo 310, el «obligado por ley tributaria a llevar contabilidad mercantil, libros o registros fiscales», sólo éstos, en principio, pueden ser autores del delito, lo que no impide que terceros intervengan como inductores, cooperadores necesarios o cómplices.

\section{RESPONSABILIDAD DE LAS PERSONAS JURÍDICAS}

Dispone el artículo 310 bis:

"Cuando de acuerdo con lo establecido en el artículo 31 bis una persona jurídica sea responsable de los delitos recogidos en este Título, se le impondrán las siguientes penas:

a) Multa del tanto al doble de la cantidad defraudada o indebidamente obtenida, si el delito cometido por la persona física tiene prevista una pena de prisión de más de dos años.

b) Multa del doble al cuádruple de la cantidad defraudada o indebidamente obtenida, si el delito cometido por la persona física tiene prevista una pena de prisión de más de cinco años.

c) Multa de seis meses a un año, en los supuestos recogidos en el artículo 310.

Además de las señaladas, se impondrá a la persona jurídica responsable la pérdida de la posibilidad de obtener subvenciones o ayudas públicas y del derecho a gozar de los beneficios o incentivos fiscales o de la Seguridad Social durante el período de tres a seis años. Podrá imponerse la prohibición para contratar con las Administraciones Públicas.

Atendidas las reglas establecidas en el artículo 66 bis, los Jueces y Tribunales podrán asimismo imponer las penas recogidas en las letras b), c), d), e) y g) del apartado 7 del artículo $33 »^{43}$.

${ }^{43} \mathrm{El}$ art. 33.7 del C.p. se ocupa de las penas aplicables a las personas jurídicas, que tienen todas la consideración de graves. Entre ellas el apartado b) se ocupa de la disolución de las personas jurídicas...; el c) a la suspensión de sus actividades por un plazo no superior a cinco años; el d) a la clausura de locales y establecimientos por un plazo no superior a cinco años; el e) prohibición de realizar en el futuro determi- 
La pena de multa está en función de la pena de prisión que correspondería al delito cometido por la persona física.

En el apartado a) hay que entender que es prisión de más de dos años y no supere los cinco (arts. 305.1 y 3, 306, 307.1, 307 ter.1, 308.1. y 2). En el b) prisión de más de cinco años y que no exceda de seis (hay que tener en cuenta que la prisión puede llegar hasta seis años en los supuestos de los arts. 305 bis.1, 307 bis. 1 y 307 ter.2.

Hay supuestos que escapan al artículo 310 bis ya que la pena establecida no supera los dos años, como sucede en el párrafo segundo del artículo 305.3 en las defraudaciones contra la Hacienda de la Unión Europea que tiene prevista una pena de prisión de tres meses a un año o multa, cuando la cuantía defraudada fuera superior a cuatro mil euros y no superase los cincuenta mil. También hay que tener en cuenta los supuestos atenuados en los que la pena de prisión se puede rebajar en uno o dos grados, como sucede en el artículo 305.6, 307.5 y 308.7.

\section{PROCEDIMIENTO}

La Administración tributaria se abstendrá de intervenir cuando el fraude tributario pudiera ser constitutivo de delito.

Dispone el artículo 180.1 de la LGT en sus dos primeros párrafos: «Si la Administración tributaria estimase que la infracción pudiera ser constitutiva de delito contra la Hacienda Pública, pasará el tanto de culpa a la jurisdicción competente, o remitirá el expediente al Ministerio Fiscal y se abstendrá de seguir el procedimiento administrativo, que quedará suspendido mientras la autoridad judicial no dicte sentencia firme, tenga lugar el sobreseimiento o el archivo de las actuaciones o se produzca la devolución del expediente por el Ministerio Fiscal. La sentencia condenatoria de la autoridad judicial impedirá la imposición de sanción administrativa». Si no se aprecia delito la administración tributaria continuará las acciones ${ }^{44}$.

nadas actividades y g) intervención judicial para salvaguardar los derechos de los trabajadores o de los acreedores...

${ }^{44}$ Según el párrafo tercero del artículo 180.1 de la LGT: De no haberse apreciado la existencia de delito, la Administración tributaria iniciará o continuará sus actuaciones de acuerdo con los hechos que los tribunales hubieran considerado probados, y se reanudará el cómputo del plazo de prescripción en el punto en el que estaba cuando se suspendió. Las actuaciones administrativas realizadas durante el período de suspensión se tendrán por inexistentes. 
Supuestos de regularización. Si el obligado tributario ha regularizado su situación mediante el reconocimiento y pago de la deuda, aunque la infracción en algún momento pudo ser constitutiva de delito, la Administración tributaria continuará el procedimiento sin comunicarlo a la autoridad judicial o Ministerio Fiscal. A este respecto recoge el artículo 180.2 de la LGT: «Si la Administración tributaria estimase que el obligado tributario, antes de que se le haya notificado el inicio de actuaciones de comprobación o investigación, ha regularizado su situación tributaria mediante el completo reconocimiento y pago de la deuda tributaria, la regularización practicada le exoneraría de su responsabilidad penal, aunque la infracción en su día cometida pudiera ser constitutiva de delito contra la Hacienda Pública, y la Administración podrá continuar con el procedimiento administrativo sin pasar el tanto de culpa a la autoridad judicial ni al Ministerio Fiscal. Asimismo, los efectos de la regularización prevista en el párrafo anterior, resultarán aplicables cuando se satisfagan deudas tributarias una vez prescrito el derecho de la Administración a su determinación».

Prescripción. De acuerdo con lo que dispone el artículo 131.1 del C.p. los delitos contra la Hacienda Pública y contra la Seguridad Social prescriben a los cinco años, cuando el límite superior de la pena de prisión no supere los cinco años (artículos 305.1 y 3, 306, 307.1 y 307 ter.1) y a los diez para los supuestos donde el máximo de la pena es de seis años (artículos 305 bis.1 y 307 bis.1).

Según el artículo 66 de la LGT: «Prescribirán a los cuatro años los siguientes derechos: a) El derecho de la Administración para determinar la deuda tributaria mediante la oportuna liquidación. b) El derecho de la Administración para exigir el pago de las deudas tributarias liquidadas y autoliquidadas. c) El derecho a solicitar las devoluciones derivadas de la normativa de cada tributo, las devoluciones de ingresos indebidos y el reembolso del coste de las garantías. d) El derecho a obtener las devoluciones derivadas de la normativa de cada tributo, las devoluciones de ingresos indebidos y el reembolso del coste de las garantías».

\section{PROYECTO DE LEY DE REFORMA DEL CÓDIGO PENAL}

En el Proyecto de Ley de reforma del Código penal de $2013^{45}$ se modifica el artículo 306 y se introduce un nuevo artículo 308 bis.

${ }^{45}$ Proyecto de Ley Orgánica por la que se modifica la Ley Orgánica 10/1995, de 23 de noviembre, del Código penal (BOCG, Congreso de los Diputados, Serie A, núm. 66.1, de 4 de octubre de 2013). 
Los delitos contra la Hacienda Pública y la Seguridad Social se han modificado en varias ocasiones: 2003, 2010 y 2012 ${ }^{46}$. Tantas reformas ponen de manifiesto la inseguridad del legislador. Ello se confirma con el primer texto del Anteproyecto de reforma del Código, que aparece en julio de 2012 -cinco meses antes de la reforma de diciembre de 2012- donde se recoge la modificación del apartado 3 del artículo 305 (defraudaciones contra la Hacienda Pública de la Comunidad Europea), del artículo 306(defraudaciones en los presupuestos generales de la Unión Europea) y artículo 309 (obtención indebida de fondos de los presupuestos generales de la Unión Europea u otros administrados por ésta). Estos artículos se refunden en la reforma de 2012 en los artículos 305.3 y 306. El texto del Anteproyecto aprobado en el Consejo de Ministros de 11 de octubre de 2012 no recoge las reformas propuestas en el primer texto, incorporando un artículo, el 308 bis. Hay un nuevo texto del Anteproyecto, de 13 de abril de 2013, que no pasó por el Consejo de Ministros, donde se mantiene la incorporación del artículo 308 bis. Por último, el Proyecto aprobado el 20 de septiembre de 2013 mantiene la inclusión del nuevo artículo 308 bis e incorpora la modificación del artículo 306.

\section{Modificación del artículo 306}

En el Proyecto se modifica el párrafo primero del artículo 306. Introduce un inciso final con el siguiente contenido: «...y la pérdida de la posibilidad de obtener subvenciones o ayudas públicas y del derecho a gozar de los beneficios o incentivos fiscales o de la Seguridad Social durante el período de tres a seis años».

\section{Suspensión de la ejecución de la pena}

El nuevo artículo 308 bis, que se incorpora queda redactado como sigue: «1. La suspensión de la ejecución de las penas impuestas por alguno de los delitos regulados en este Título se regirá por las disposiciones contenidas en el Capítulo III del Título III del Libro I de este Código, completadas por las siguientes reglas: $1 .^{\mathrm{a}}$ La suspensión de la ejecución de la pena de prisión impuesta requerirá, además del cumplimiento de los requisitos regulados en el artículo 80, que el penado

${ }^{46}$ Se modifican por las siguientes normas: LO 15/2003, de 25 de noviembre; LO 5/2010, de 12 de julio; LO 7/2012, de 27 de diciembre. 
haya abonado la deuda tributaria o con la Seguridad Social, o que haya procedido al reintegro de las subvenciones o ayudas indebidamente recibidas o utilizadas».

Según se ha expuesto en este trabajo, el legislador, dentro de una política criminal recaudatoria, facilita la posibilidad de no ingresar en prisión, siempre que se haya regularizado la situación tributaria. Sin embargo, ahora veremos cómo en relación a los que no han reintegrado la cantidad defraudada se le ponen más dificultades para concederle la suspensión de la ejecución de la pena. En realidad son muy pocas las condenas superiores a dos años -que obligaría a ingresar en prisión a los autores de un delito contra la Hacienda pública o contra la Seguridad Social- a pesar que la pena privativa de libertad prevista en el Código para la mayor parte de los supuestos tiene un límite máximo de seis años, y en los supuestos agravados de seis.

Compromiso de satisfacer la deuda tributaria, $u$ otras subvenciones o ayudas indebidamente recibidas

Hay supuestos en los que el condenado a pesar de que deseara satisfacer la deuda contraída no puede hacerlo por carecer de los medios suficientes. En estos casos es suficiente con que se asuma el compromiso de hacerlo. A este respecto recoge el párrafo segundo del artículo 308 bis.1,1. ${ }^{\mathrm{a}}$

"Este requisito se entenderá cumplido cuando el penado asuma el compromiso de satisfacer la deuda tributaria, la deuda frente a la Seguridad Social o de proceder al reintegro de las subvenciones o ayudas indebidamente recibidas o utilizadas y las responsabilidades civiles de acuerdo a su capacidad económica y de facilitar el comiso acordado, y sea razonable esperar que el mismo será cumplido. La suspensión no se concederá cuando conste que el penado ha facilitado información inexacta o insuficiente sobre su patrimonio».

Los requisitos que se exigen en el texto legal son:

a) Que el compromiso de reintegrar las cantidades defraudadas estará en función de la capacidad económica.

b) Facilitar el comiso de la cantidad acordada.

Denegación de la suspensión. Según dispone el inciso último del párrafo segundo, recogido más arriba: no se concederá la suspensión de la ejecución de la pena «cuando conste que el penado ha facilitado información inexacta o insuficiente sobre su patrimonio». 
Comunicación de la suspensión a los órganos competentes

Dispone el párrafo tercero del artículo 308 bis.1,1. « «La resolución por la que el Juez o Tribunal concedan la suspensión de la ejecución de la pena será comunicada a la representación procesal de la Hacienda Pública estatal, autonómica, local o foral, de la Seguridad Social o de la Administración que hubiera concedido la subvención o ayuda».

Revocación de la suspensión

«El Juez o Tribunal revocarán la suspensión y ordenarán la ejecución de la pena, además de en los supuestos del artículo 86, cuando el penado no dé cumplimiento al compromiso de pago de la deuda tributaria o con la Seguridad Social, al de reintegro de las subvenciones $\mathrm{y}$ ayudas indebidamente recibidas o utilizadas, o al de pago de las responsabilidades civiles, siempre que tuviera capacidad económica para ello; o facilite información inexacta o insuficiente sobre su patrimonio. En estos casos, el Juez de Vigilancia Penitenciaria podrá denegar la concesión de la libertad condicional» (artículo 308 bis. 1, 2. ${ }^{\mathrm{a}}$.

Se aprecia una mayor exigencia para la suspensión de la ejecución en los delitos contra la Hacienda pública y contra la Seguridad Social, pues, además de los requisitos generales del artículo 86, se agregan otros.

Se contemplan tres supuestos:

a) El Juez o Tribunal ordenará la ejecución de la pena cuando el penado no haya cumplido con su compromiso de pago, siempre que tuviera capacidad económica para ello.

b) Impago de las responsabilidades civiles cuando tuviera capacidad económica para hacerlo.

c) Haber facilitado información inexacta o insuficiente sobre su patrimonio.

\section{Libertad condicional}

Dentro de las mayores exigencias para los autores de estos delitos, se impone una más, aunque sea potestativa. Según dispone el inciso final del artículo 308 bis.1,2. ${ }^{\mathrm{a}}$ "En estos casos, el Juez de Vigilancia Penitenciaria podrá denegar la concesión de la libertad condicional». 


\section{Fraccionamiento del reintegro de la deuda a efectos de responsabilidad civil}

El artículo 125 del Código penal se ocupa del cumplimiento de la responsabilidad civil y otras responsabilidades pecuniarias. Prevé la posibilidad del fraccionamiento de la responsabilidad civil cuando los bienes del obligado «no sean bastantes para satisfacer de una vez las responsabilidades pecuniarias».

Dispone el artículo 308 bis.2: «En el supuesto del artículo 125, el Juez o Tribunal oirán previamente a la representación procesal de la Hacienda Pública estatal, autonómica, local o foral, de la Seguridad Social o de la Administración que hubiera concedido la subvención o ayuda, al objeto de que aporte informe patrimonial de los responsables del delito en el que se analizará la capacidad económica y patrimonial real de los responsables y se podrá incluir una propuesta de fraccionamiento acorde con dicha capacidad y con la normativa tributaria, de la Seguridad Social o de subvenciones».

Así como en el artículo 125 la referencia es general a los bienes del responsable civil, pudiendo la parte perjudicada justificarlos por cualquier procedimiento ante el Juez o Tribunal, en los delitos que aquí nos ocupan en la información del patrimonio de los responsables del delito, el Juez o Tribunal oirán previamente a los representantes procesales de los organismos defraudados. 